WieSŁaWA GIERAŃCZYK

Uniwersytet Mikołaja Kopernika, Toruń

\title{
Badanie struktur przemysłowych w Polsce w dobie globalizacji ze szczególnym uwzględnieniem struktury przestrzennej
}

Globalizacja jako siła napędzająca przemiany społeczno-gospodarcze i polityczne kształtuje nowy porządek współczesnego świata. Imperatyw stałego wzrostu gospodarczego wymusza poszukiwanie nowych źródeł optymalizacji działalności przemysłowej m.in. poprzez daleko posunięty podział pracy, poszukiwanie taniej siły roboczej, specjalizację działalności, zacieśnianie więzi pomiędzy poszczególnymi sektorami gospodarki narodowej, wykorzystywanie nowoczesnych osiagnięć technologicznych, nowe rozwiązania organizacyjne (fragmentacja produkcji), działania polityczne (systematyczna redukcja barier w przepływach dóbr, usług i kapitału w skali światowej). W konsekwencji wzajemnego oddziaływania tych czynników w gospodarce światowej zacieśniają się związki między przedsiębiorstwami, działami gospodarki narodowej, zacieśniają się też powiązania przestrzenne. Prowadzi to do postępującego przenikania i integrowania się rynków (krajowych i regionalnych) oraz umiędzynarodowienia produkcji, dystrybucji i marketingu.

Globalizacja wywołuje też daleko idące zmiany w funkcjonowaniu przemysłu. W konsekwencji zmienia się przedmiot badań geografii przemysłu, zmienia się też zakres merytoryczny i badawczy struktur (układów) przemysłowych. Szczególnie ważne w aspekcie badawczym są uwarunkowania zewnętrzne wpływające na kształtowanie struktur przemysłowych jako elementu szerszego procesu, który określa miarę przejścia od cywilizacji przemysłowej do cywilizacji informatycznej (Zioło 2003).

Tradycyjnie analiza układów strukturalnych dokonywana była w następujących płaszczyznach: działowej (branżowej, gałęziowej), własnościowej, wielkościowej, przestrzennej. W dobie globalizacji, wskutek intensywnego oddziaływania na przemysł osiagnnięć nauki i techniki, zwłaszcza w sferze organizacyjnej, technologicznej, ale także logistycznej, wyodrębnienie każdej z wymienionych struktur nastręcza wiele trudności.

Podstawą identyfikacji struktury działowej są klasyfikacje działalności gospodarczej, zwykle opracowane w ujęciu przedmiotowym, jednakże coraz trudniej jest przyporządkować wytwory przedsiębiorstw do określonej działalności gospodarczej. Wiąże się to z realizacją przez firmy strategii polegających na dywersyfikacji działalności celem minimalizacji ryzyka działania na rynku (zwłaszcza rynku globalnym), z procesami integracji przedsiębiorstw (powstawanie form konglomeratowych), ale także ze wzrostem znaczenia produktów niezwiązanych z przetwarzaniem materialnego substratu, które stają się istotnym zasobem produkcyjnym. Uusługowienie przemysłu wyraża się też wzrostem elastyczności organizacji 
procesu produkcyjnego (np. poprzez rozwój outtaskingu' ${ }^{1}$ ). Poza nowoczesną formą przekazu informacji outtasking przyczynia się do większej integracji zleceniodawcy i dostawcy usług, co pozwala na skrócenie czasu wykonania zadania (Hirzel 1997). Zastępowanie pracy fizycznej pracą wymagającą dużego udziału informacji i wiedzy stwarza nowy wymiar tego pojęcia (np. telepraca) oraz nowe możliwości rozwoju przedsiębiorstw, dla których lokalizacja w sensie fizycznym traci na znaczeniu.

Tylko w kontekście tak ogólnie zarysowanych rozważań pojawia się też trudność w identyfikowaniu struktury wielkościowej przedsiębiorstw przemysłowych. Problemy rodzą się już w momencie ustalenia miar wielkości przedsiębiorstwa. W dobie globalizacji tradycyjne mierniki wielkości zatrudnienia tracą na znaczeniu na rzecz mierników efektywności ekonomicznej, takich jak: wartość dodana, przychody, zysk, oraz miar syntetycznych oceniających innowacyjność czy umiędzynarodowienie. Badanie tych aspektów wielkości przedsiębiorstw ogranicza przede wszystkim dostęp do danych źródłowych chronionych przez przedsiębiorstwa przed konkurencją, a przez instytucje statystyczne obowiązkiem zachowania tajemnicy statystycznej.

Narastająca złożoność przestrzeni geograficznej sprawia, że występują poważne trudności w identyfikowaniu układów przestrzennych działalności przemysłowej. Składają się na to wielopłaszczyznowe relacje przedsiębiorstw przemysłowych z elementami otoczenia oraz skomplikowany układ powiązań rynkowych (Zioło 2003). W dobie Internetu, który pozwala na świadczenie usług w czasie rzeczywistym, powszechną formą kooperacji przedsiębiorstw są sieci. Sieci przedsiębiorstw charakteryzują silne powiązania kooperacyjne pomiędzy poszczególnymi ogniwami układu, którym towarzyszą słabe powiązania kapitałowe. Sieci przyjmują różne postaci: od form geograficznie skoncentrowanych $\left(\right.$ klastry $\left.^{2}\right)$ po przedsiębiorstwa wirtualne ${ }^{3}$. Przedsiębiorstwa wirtualne nie mają granic, a ich przewaga konkurencyjna budowana jest m.in. przez tworzenie zindywidualizowanego produktu zaspokajającego specyficzne potrzeby klienta oraz elastyczną formę powiązań wytwórcy dobra z centrum strategicznym. Przedsiębiorstwa wirtualne wykorzystują także zasadę synergii, zatrudniają niewielką liczbę pracowników, a realizację różnorodnych zamówień zlecają licznym kontrahentom.

Inną formą poszukiwania dróg podnoszenia konkurencyjności przedsiębiorstw przemysłowych są nasilające się procesy koncentracji ${ }^{4}$ decyzyjnej i organizacyjnej przedsiębiorstw przemysłowych, które prowadzą do powstawania korporacji (międzynarodowych). Korporacje powstają poprzez rozwój własnych zakładów, tworzenie nowych oddziałów (poza granicami) oraz włączanie w swoje struktury innych firm. Rosnące rozmiary korporacji wymuszają poszukiwanie dróg efektywności ekonomicznej poza granicami lokalizacji firmy macierzystej korporacji (nienasyconych rynków, źródeł taniej i wykwalifikowanej siły roboczej), kreując nowe zjawiska, takie jak: outsourcing, offshoring, labelling, redeployment, delokalizacja. W konsekwencji w dobie globalizacji korporacje (międzynarodowe) stanowią dominujące ogniwo łańcuchów produkcji. W takich warunkach najbardziej

\footnotetext{
${ }^{1}$ Outtasking - zlecanie podwykonawcom części zadań prowadzących do powstania produktu czy usługi w formie elektronicznej i otrzymywanie wyników tych prac również w formie elektronicznej.

${ }^{2}$ Znajdująca się w geograficznym sąsiedztwie grupa przedsiębiorstw i powiązanych z nimi instytucji zajmujących się określoną dziedzina, połączoną podobieństwami i wzajemnie się uzupełniającą (Porter 2001).

${ }^{3}$ Przedsiębiorstwo wirtualne jest zgrupowaniem partnerów pracujących ze sobą za pośrednictwem Internetu.

${ }^{4}$ Formy koncentracyjne to związki przedsiębiorstw polegające na ich łączeniu, w związku z tym między przedsiębiorstwami następują powiązania kapitałowe, na skutek których następuje ograniczenie ekonomicznej samodzielności przedsiębiorstw.
} 
obiektywną jednostką badań strukturalnych jest organizacja przemysłowa. Organizacja, według Domańskiego (1982), określa sposób, według którego elementy jakiegoś zbioru są porządkowane w całość i wyznaczane do pełnienia określonych funkcji. Badanie lokalizacji przestrzennej organizacji powinno obejmować nie tylko lokalizacje i powiązania między poszczególnymi elementami łańcucha produkcji zaopatrzenie-produkcja-dystrybucja (Stryjakiewicz, Wajda 2003). W związku z tym, iż formy kooperacyjne i koncentracyjne przedsiębiorstw nieustannie ewoluują, badanie struktury własnościowej, widziane przez pryzmat zaangażowania kapitałowego właścicieli oraz form zależności kapitałowych (typy spółek i ich hierarchia w wymiarze przestrzennym), jest niezmiernie trudne.

Powstanie i kształtowanie się przestrzennych form koncentracji uwarunkowane jest różnorodnymi czynnikami, które stanowią funkcję natężenia sił skupienia przestrzennego potencjału produkcyjnego i czasu. Skupiska przemysłowe różnią się od siebie pod względem zasięgu, zainwestowania, struktury produkcji, powiązań techniczno-ekonomicznych itp., dlatego ich delimitacja nastręcza wiele trudności. Stosując daleko idące uogólnienie, można stwierdzić, że w literaturze przedmiotu panuje pogląd, iż podstawowym elementem koncentracji przemysłu jest zakład przemysłowy, natomiast najwyższą formą koncentracji działalności przemysłowej jest okręg przemysłowy (Problematyka... 1990). Istotne rozbieżności występują przy hierarchizacji i określaniu poszczególnych typów przestrzennych form koncentracji przemysłu (m.in. Chardonnet 1955; Fierla 1984, 1987, Misztal, 1970, Pakuła 1978, Secomski 1956, Zioło 1971). Większość dotychczas przeprowadzonych badań przemysłowych struktur przestrzennych w Polsce opierała się głównie na wskaźnikach zatrudnienia (tab. 1).

Tabela 1. Wybrane delimitacje okręgów przemysłowych

\begin{tabular}{|c|c|c|}
\hline Autor & $\begin{array}{c}\text { Dane statystyczne } \\
\text { z roku }\end{array}$ & \\
\hline $\begin{array}{l}\text { Wincenty } \\
\text { Kawalec }\end{array}$ & 1965 & $\begin{array}{l}\text { W. Kawalec (1970) do okręgów przemysłowych zaliczył powia- } \\
\text { ty, które charakteryzowały się wysokimi wskaźnikami zatrud- } \\
\text { nienia w przemyśle na } 100 \text { mieszk. (pow. } 160 \text { osób) i na } 10 \mathrm{~km}^{2} \\
\text { oraz wysokimi nakładami inwestycyjnymi. }\end{array}$ \\
\hline $\begin{array}{l}\text { Stanisław } \\
\text { Misztal }\end{array}$ & 1960 & $\begin{array}{l}\text { S. Misztal (1970) do okręgów przemysłowych zaliczył miasta, } \\
\text { osiedla i gromady, w których: } \\
\text { 1) wskaźnik zatrudnienia w przemyśle według miejsc pracy na } \\
10 \mathrm{~km}^{2} \text { nie jest niższy od średniego wskaźnika krajowego; } \\
\text { 2) wskaźnik zatrudnienia w przemyśle według miejsc zamiesz- } \\
\text { kania na } 1000 \text { ludności nie jest niższy od średniego wskaźni- } \\
\text { ka krajowego; } \\
\text { 3) istnieje ciagłość terytorialna (bezpośrednie sąsiedztwo) } \\
\text { jednostek wchodzących w skład okręu; } \\
\text { 4) maksymalna odległość między ośrodkami wchodzącymi } \\
\text { w skład okregu nie przekracza } 25 \mathrm{~km} \text {; } \\
\text { 5) łączne zatrudnienie w przemyśle na obszarze w ten sposób } \\
\text { wyznaczonym nie jest niższe od } 1 \% \text { ogólnokrajowego za- } \\
\text { trudnienia w przemyśle lub wartość produkcji globalnej } \\
\text { przemysłu nie niższa od } 1 \% \text { wartości globalnej produkcji } \\
\text { przemysłowej kraju. }\end{array}$ \\
\hline
\end{tabular}




\begin{tabular}{|c|c|c|}
\hline $\begin{array}{l}\text { Stanisław } \\
\text { Misztal }\end{array}$ & 1960 & $\begin{array}{l}\text { Przy delimitacji okręgów bezpośrednio ze sobą sąsiadujących } \\
\text { uwzględniono ponadto procesy historycznego formowania się } \\
\text { okręgów, natężenie i kierunki dojazdów do pracy w przemyśle, } \\
\text { a także informacje o powiązaniach energetycznych, surowco- } \\
\text { wych, kooperacyjnych i rynkowych poszczególnych ośrodków. }\end{array}$ \\
\hline $\begin{array}{l}\text { Antoni } \\
\text { Wrzosek }\end{array}$ & 1965 & $\begin{array}{l}\text { A. Wrzosek (1972) do okręgów przemysłowych zaliczył powia- } \\
\text { ty, które spełniały co najmniej jeden z warunków ustalonych } \\
\text { przez GUS: } \\
\text { 1) zatrudnienie w przemyśle na } 1000 \text { mieszkańców wynosi po- } \\
\text { nad } 160 \text { osób; } \\
\text { 2) zatrudnienie w przemyśle na } 100 \mathrm{~km}^{2} \text { jest dwukrotnie wyższe } \\
\text { od średniej krajowej; } \\
\text { 3) nakłady inwestycyjne przeznaczone na rozwój przemysłu wy- } \\
\text { niosły w latach 1961-1965 ponad } 400 \text { mln zł w c. b.; } \\
\text { 4) położone są w bezpośrednim zasięgu oddziaływania gospo- } \\
\text { darczego wielkich ośrodków przemysłowych. }\end{array}$ \\
\hline $\begin{array}{l}\text { Stanisław } \\
\text { Misztal }\end{array}$ & 1970 & $\begin{array}{l}\text { Kryteria takie jak w przypadku wcześniejszej delimitacji (uaktu- } \\
\text { alnione dane) (w: Leszczycki, Lijewski 1974) }\end{array}$ \\
\hline Irena Fierla & 1970 & $\begin{array}{l}\text { I. Fierla (1987) do okręów przemysłowych zaliczyła jedno- } \\
\text { stki terytorialne: miasta, osiedla i gromady sąsiadujące ze sobą, } \\
\text { w których: } \\
\text { 1) ludność czynna zawodowo w przemyśle wytwarzała więcej } \\
\text { produkcji czystej niż zatrudniona w jakimkolwiek innym } \\
\text { dziale gospodarki narodowej; } \\
\text { 2) dochody ludności otrzymywane z tytułu pracy w przemyśle } \\
\text { przekraczały na tych terenach zarobki uzyskiwane w którym- } \\
\text { kolwiek z pozostałych produkcyjnych działów gospodarki } \\
\text { narodowej; } \\
\text { 3) pod uwagę wzięto również proporcje produkcji czystej w } \\
\text { przemyśle i rolnictwie na jednego zatrudnionego oraz od- } \\
\text { setek ludności czynnej zawodowo w każdym z tych dwu } \\
\text { działów. }\end{array}$ \\
\hline GUS & 1980 & $\begin{array}{l}\text { Opublikowana w } 1982 \text { r. mapa okręgów przemysłowych Polski } \\
\text { wykonana została na zlecenie GUS przez J. Wojtan, S. Rolę-Ku- } \\
\text { nach i S. Misztala (Delimitacja... 1982). Delimitację przeprowa- } \\
\text { dzono na podstawie wskaźników uprzemysłowienia miast i gmin } \\
\text { (źródłem były dane z NSP } 1978 \text { r.), m.in.: } \\
\text { 1) procentowego udziału czynnych zawodowo w przemyśle do } \\
\text { ogólnej liczby ludności, } \\
\text { 2) wskaźnika gęstości zawodowo czynnych w przemyśle, } \\
\text { 3) dojazdów do pracy w przemyśle, } \\
\text { 4) koncentracji zatrudnionych w przemyśle w stosunku do ogółu } \\
\text { zatrudnionych. }\end{array}$ \\
\hline \multirow[t]{2}{*}{ GUS } & 1988 & GUS (Delimitacja... 1994) na podstawie danych NSP z 1988 roku. \\
\hline & & $\begin{array}{l}\text { W. Gierańczyk, A. Stańczyk }(2000,2001) \text { - próba delimitacji } \\
\text { polskiej przestrzeni przemysłowej na podstawie jednostek tery- } \\
\text { torialnych. Założono, że przestrzeń przemysłową tworzą powia- } \\
\text { ty, w których: }\end{array}$ \\
\hline
\end{tabular}




\begin{tabular}{|c|c|c|}
\hline $\begin{array}{l}\text { Wiesława } \\
\text { Gierańczyk, } \\
\text { Arkadiusz } \\
\text { Stańczyk }\end{array}$ & 1998 & $\begin{array}{l}\text { 1) wskaźnik koncentracji pracujących w przemyśle na } 1 \mathrm{~km}^{2} \text { prze- } \\
\text { kracza wartości średnie dla Polski }\left(11,7 \text { pracujących } / \mathrm{km}^{2}\right) \text {, } \\
\text { 2) udział pracujących do ogólnej liczby ludności danego obszaru } \\
\text { przekracza wartości średnie dla Polski }(9 \%) \text {; } \\
\text { 3) liczba pracujących w przemyśle na wyodrębnionym obszarze } \\
\text { stanowi co najmniej } 1 \% \text { ogólnej liczby pracujących w prze- } \\
\text { myśle; } \\
\text { 4) występuje ciagłość terytorialna (bezpośrednie sąsiedztwo) jed- } \\
\text { nostek wchodzących w skład przestrzeni przemysłowej. }\end{array}$ \\
\hline
\end{tabular}

Źródło: Opracowanie własne na podstawie literatury.

Przełom XX i XXI wieku sprawił, że wskutek zmiany uwarunkowań prowadzenia działalności gospodarczej w Polsce tradycyjne formy koncentracji przemysłu straciły na znaczeniu. W warunkach globalizacji i internacjonalizacji życia gospodarczego rośnie znaczenie przewagi konkurencyjnej poszczególnych regionów jako potencjalnych miejsc prowadzenia działalności gospodarczej.

Region może bowiem przyciągać lub zniechęcać inwestorów w zależności od atrakcyjności i konkurencyjności jego przestrzeni gospodarczej, społecznej i środowiska naturalnego. Struktury regionalne biorą udział w wyścigu o uzyskanie trwałych szans na przyspieszony rozwój. System funkcjonowania regionu i jego struktury stają się głównym zasobem strategicznym, który pozwala uzyskać przewagę nad innymi regionami i pozyskać potencjalnych inwestorów. Okazuje się, że odległość fizyczna pomiędzy poszczególnymi przedsiębiorstwami, ich terytorialne osadzenie, ma dużo większe znaczenie niż to wynika z opinii badaczy globalizacji, deprecjonujących znaczenie czynnika przestrzeni. Uzyskanie wyższego poziomu konkurencyjności w globalizującej się gospodarce umożliwia integracja regionalna przybierająca postać klastrów ${ }^{5}$. Klaster jest strukturą ułatwiającą przepływ informacji, sprzyjającą procesom uczenia się i pobudzającą innowacyjność. Funkcjonowanie klastra prowadzi do poprawy zdolności konkurencyjnych podmiotów gospodarczych w nim uczestniczących. Klaster nie jest jednak prostą sumą poszczególnych podmiotów, ale powstałą w wyniku interakcji i synergii przestrzenną formą organizacji produkcji zwiększająca elastyczność i konkurencyjność (Porter 2001). W sieć powiązań klastra poza przedsiębiorstwami przemysłowymi włączone są również inne instytucje i organizacje, takie jak ośrodki naukowe, jednostki badawczo-rozwojowe czy organizacje prywatne. Wyzwala to znaczny potencjał innowacyjny takiej formy organizacyjno-przestrzennej przemysłu. Wzajemne powiązania poszczególnych podmiotów mają często charakter nieformalny i w części bazują na dużej rotacji kadr wewnątrz klastra. Liczne powiązania pomiędzy podmiotami klastra sprawiają że podążają one tą samą trajektorią rozwoju. O fenomenie klastra decydują: koncentracja przestrzenna, jednoczesna konkurencja i kooperacja oraz wspomniana wcześniej wspólna trajektoria rozwoju (Polityka... 2004). Efekt synergiczny klastra przemysłowego wyzwalać może efekt sąsiedztwa ${ }^{6}$ i efekt naśladownictwa ${ }^{7}$.

${ }^{5}$ Klaster to znajdująca się w geograficznym sąsiedztwie grupa przedsiębiorstw i powiązanych z nimi instytucji zajmujących się określoną dziedziną, połączona podobieństwami i wzajemnie się uzupełniająca (Porter 2001).

${ }^{6}$ Ang. border effect - w jednostkach sąsiadujących obserwowana jest zwiększona synchronizacja działalności gospodarczej (Skrzypczyński 2006).

${ }^{7}$ Rozwój jednej jednostki pobudza, a niekiedy wręcz wymusza rozwój pozostałych jednostek. 
Powyższa teza stała się podstawą podjęcia rozważań nad przydatnością analizy autokorelacji przestrzennej do identyfikacji wzorców zależności przestrzennej oraz przestrzennej heterogeniczności działalności przemysłowej na przykładzie woj. kujawsko-pomorskiego. Główne założenie analizy autokorelacyjnej opiera się na stwierdzeniu, że natężenie zjawisk w jednostce przestrzennej $i$ zależy od poziomu tego zjawiska w jednostkach sąsiedzkich. Zatem ,jeżeli występowanie pewnego zjawiska w jednej jednostce przestrzennej powoduje zwiększenie lub zmniejszenie prawdopodobieństwa występowania tego zjawiska w sąsiednich jednostkach, to zjawisko to pokazuje autokorelację przestrzenną" (Bivand 1981). Zjawisko autokorelacji przestrzennej jest konsekwencją występowania zależności przestrzennych. Wynika to z faktu, iż dane analizowane w badaniach przestrzennych są ściśle związane z jednostkami odniesienia (regiony, powiaty, gminy). Przyporządkowanie takie nie odzwierciedla dokładnie natury większości zjawisk, gdyż granice sztucznie wyznaczone nie są zazwyczaj ogranicznikami ludzkiej aktywności. Ponadto przestrzenny wymiar społeczno-ekonomicznej działalności jest w znacznym stopniu kształtowany przez dystans i lokalizacje, co przejawia się w teoriach i koncepcjach geografii, m.in. dyfuzji innowacji, biegunów wzrostu (LaSage 1999). Zatem na gruncie relacji zjawisko-przestrzeń autokorelację należy rozumieć jako częstsze niż losowe podobieństwo bliskich sobie przestrzennie obserwacji. Jeżeli blisko siebie położone są grupy regionów o podobnych wartościach, można uznać, że zachodzi między nimi autokorelacja przestrzenna. Jeżeli ta korelacja dotyczy składnika losowego, można spodziewać się, że szoki w jednym regionie będą przenosić się na inne regiony i obserwowana będzie dyfuzja. Na poziomie statystycznym autokorelacja przestrzenna pozwala wyodrębnić klastry podobnych do siebie regionów. Jednak w skrajnym przypadku, kiedy obserwowane są tylko dwa klastry, wysokich i niskich wartości, które obejmują wszystkie obserwacje, mamy do czynienia z heterogenicznością przestrzenną. Jest to dość problematyczne zjawisko z punktu widzenia aplikacji metod przestrzennych. Taki dualizm w danych bez zastosowania zmiennych kontrolnych prowadzić może do błędnych wniosków. W praktyce dość trudno odróżnić autokorelację przestrzenną od heterogeniczności przestrzennej. O ile autokorelacja może być modelowana, o tyle heterogeniczność musi być kontrolowana, ale najpierw zdiagnozowana (Kopczewska 2007).

Na istotność zależności przestrzennej i możliwości określania na tej podstawie autokorelacji przestrzennej zwracali uwagę m.in. Cliff, Ord (1973), Haggett, Cliff, Frey (1977), Czyż (1978), Ratajczak (1980), Bivand (1981), Anselin, Bera (1998), LeSage (1999), Smirnov, Anselin (2001).

Podstawowym elementem wszystkich analiz przestrzennych jest określenie struktury sąsiedztwa za pomocą tzw. wag przestrzennych, co umożliwia szacowanie wpływu regionów sąsiedzkich na badane procesy w danym regionie. Wagi przestrzenne można określić przy założeniu kryterium styczności bądź dystansu. Najpowszechniejszym podejściem jest przyjęcie istnienia wspólnych oddziaływań tylko pomiędzy regionami, które mają wspólną granicę. Tworzona jest więc macierz binarna, z elementami 1, gdy regiony mają wspólną granicę, i elementami 0, gdy nie są swoimi sąsiadami. Tak zbudowana macierz, nazywana macierzą wag przestrzennych według kryterium wspólnej granicy pierwszego rzędu, jest następnie standaryzowana wierszami do jedności, by zachować porównywalność wag. Drugim popularnym podejściem jest przyjęcie, że relacje przestrzenne istnieją pomiędzy wszystkimi regionami, zaś ich wagą jest odwrotność odległości. Bliższe sobie regiony oddziaływują na siebie silniej niż regiony bardziej oddalone. Aby wyznaczyć odległości pomiędzy regionami, mierzy się odległości euklidesowe pomiędzy środkami (ciężkości) regionów. Tego typu 
macierz zwana jest macierzą wag przestrzennych według kryterium odwrotnej odległości. Można także wykorzystywać macierze sąsiadów w promieniu $d$ km lub macierze $k$ najbliższych sąsiadów. Istnieją także próby konstruowania bardziej wyrafinowanych macierzy, jak macierz odległości ekonomicznej, macierz odległości społecznej, macierz Daceya, Cliffa i Orda etc. (Kopczewska 2007).

Miarami autokorelacji przestrzennej są globalne i lokalne statystyki przestrzenne. Miary globalne są syntetycznym wskaźnikiem dla całej próby i badają ogólne relacje pomiędzy obserwacjami. Wynik wskazuje na istnienie autokorelacji/heterogeniczności przestrzennej. Miary lokalne są wyznaczane dla poszczególnych obserwacji i mierzą relacje badanych regionów i ich sąsiadów. Wynik pokazuje, czy istnieją lokalne hot spots. Do najczęściej wykorzystywanych miar globalnych należy statystyka $I$ Morana, $C$ Geary'ego oraz statystyki join-count. Miary lokalne wyznaczane są dla poszczególnych obserwacji i mierzą relacje badanych regionów i ich sąsiadów, np. LISA (Local Moran I), Local Geary G, Gi Getis-Ord (Kopczewska 2007).

W niniejszym pilotażowym opracowaniu przydatność metody analizy autokorelacji przestrzennej dla identyfikacji przestrzennych struktur przemysłowych zbadano na podstawie statystyki I Morana, która wyrażą się wzorem:

$$
I=\frac{n \sum_{i} \sum_{j} w_{i j}\left(Y_{i}-Y\right)\left(Y_{j}-Y\right)}{\left(\sum_{j=i} w_{i j}\right) \sum_{i}\left(\mathrm{Y}_{\mathrm{i}}-\mathrm{Y}\right)^{2}}
$$

gdzie: $\mathrm{w}_{\mathrm{ij}}$ - waga połączeń między jednostką $i$ a $j$;

$\mathrm{Y}_{\mathrm{i}}, \mathrm{Y}_{\mathrm{j}}$ - wartości zmiennej w jednostce przestrzennej $i$ oraz $j$;

$\mathrm{Y}$ - średnia arytmetyczna wartości zmiennej dla wszystkich jednostek.

Statystyka Morana może przyjmować dwie postaci w zależności od przyjętego założenia: normalności lub randomizacji. Stąd testy istotności hipotezy zerowej oblicza się przy założeniu normalności lub randomizacji (Bivand 1980). Statystyka Morana może przyjmować wartości od ok. -1 do 1 . Wartości istotnie wyższe od 0 oznaczają istnienie dodatniej autokorelacji przestrzennej, czyli grupowanie się podobnych wartości badanej zmiennej w regionach sąsiedzkich. Wartość 0 oznacza brak autokorelacji, natomiast wartości ujemne - występowanie w jednostkach sąsiedzkich różnych wartości koło siebie.

Tabela 2. Zmienne diagnostyczne uwzględnione w badaniu

\begin{tabular}{|l|l|}
\hline $\mathrm{X}_{1}$ & Produkcja sprzedana przemysłu w zł/1 pracującego w przemyśle \\
\hline $\mathrm{X}_{2}$ & Pracujący w przemyśle i budownictwie/zatrudnienie w GN \\
\hline $\mathrm{X}_{3}$ & Przeciętne miesięczne wynagrodzenie w przemyśle i budownictwie w zł \\
\hline $\mathrm{X}_{4}$ & $\begin{array}{l}\text { Wartość brutto środków trwałych w przedsiębiorstwach przemysłowych w mln zł/1 pracujące- } \\
\text { go w przemyśle }\end{array}$ \\
\hline $\mathrm{X}_{5}$ & Produkcja sprzedana przemysłu w mln zł/wartość brutto środków trwałych \\
\hline $\mathrm{X}_{6}$ & $\begin{array}{l}\text { Przedsiębiorczość przemysłowa (zakłady osób fizycznych prowadzących działalność w prze- } \\
\text { myśle)/1000 ludności }\end{array}$ \\
\hline $\mathrm{X}_{7}$ & Nakłady inwestycyjne w przemyśle z zł/1 pracującego w przemyśle \\
\hline $\mathrm{X}_{8}$ & Wskaźnik sumaryczny rozwoju przemysłu \\
\hline
\end{tabular}

Źródło: Opracowanie własne 
W celu identyfikacji przemysłowych układów przestrzennych na przykładzie woj. kujawsko-pomorskiego podstawową jednostkę przestrzenną analizy stanowiły powiaty. Zestaw ośmiu zmiennych diagnostycznych przyjętych do badania został tak dobrany, aby uwzględnić nie tylko poziom zaawansowania procesów industrializacyjnych, ale przede wszystkim konkurencyjność działalności przemysłowej (tab. 2). Wyliczono też wskaźnik sumaryczny na podstawie wspomnianych zmiennych z przyjęciem założeń Perkala.

Zależności autokorelacyjne w powiatach woj. kujawsko-pomorskiego w zakresie rozwoju działalności przemysłowej przeprowadzono w dwóch przekrojach czasowych (2002 i 2005) na podstawie wag styczności i odległości ekonomicznej. Odległość ekonomiczna została wyliczona jako odległość euklidesowa, z uwzględnieniem 18 cech charakteryzujących rozwój społeczno-gospodarczy powiatów badanego obszaru. Wagi styczności pozwoliły określić zależności przestrzenne jednostek położonych w geograficznym sąsiedztwie, natomiast odległości ekonomiczne zależności jednostek o zbliżonym potencjale społeczno-ekonomicznym.

Z wyliczonych globalnych statystyk zależności przestrzennej Morana dla przyjętego obszaru wynika, że zależność przestrzenna jednostek w zakresie uwzględnionych cech badawczych jest znikoma (w niektórych przypadkach nieistotna statystycznie), zwykle o charakterze ujemnym (tab. 3). Oznacza to występowanie obok siebie jednostek z różnymi wartościami przyjętych miar rozwoju przemysłu obok siebie.

Tabela 3. Globalne statystyki zależności przestrzennej Morana rozwoju przemysłu w woj. kujawsko-pomorskim

\begin{tabular}{|c|c|c|c|c|c|c|c|c|c|c|c|c|c|c|c|c|}
\hline \multirow{2}{*}{ Odległość } & \multicolumn{2}{|c|}{$\mathrm{X}_{1}$} & \multicolumn{2}{|c|}{$X_{2}$} & \multicolumn{2}{|c|}{$\mathrm{X}_{3}$} & \multicolumn{2}{|c|}{$\mathrm{X}_{4}$} & \multicolumn{2}{|c|}{$\mathrm{X}_{5}$} & \multicolumn{2}{|c|}{$X_{6}$} & \multicolumn{2}{|c|}{$X_{7}$} & \multicolumn{2}{|c|}{$\mathrm{X}_{8}$} \\
\hline & 2002 & 2005 & 2002 & 2005 & 2002 & 2005 & 2002 & 2005 & 2002 & 2005 & 2002 & 2005 & 2002 & 2005 & 2002 & 2005 \\
\hline styczności & 0,063 & $-0,153$ & 0,027 & 0,001 & $-0,035$ & $-0,104$ & $-0,171$ & $-0,096$ & 0,007 & $-0,022$ & $-0,144$ & 0,095 & $-0,011$ & $-0,038$ & $-0,030$ & $-0,233$ \\
\hline ekonomiczna & $-0,074$ & $-0,073$ & $-0,093$ & $-0,080$ & $-0,125$ & $-0,075$ & $-0,143$ & $-0,129$ & $-0,135$ & $-0,121$ & $-0,112$ & $-0,039$ & $-0,103$ & $-0,092$ & $-0,135$ & $-0,082$ \\
\hline
\end{tabular}

Źródło: Opracowanie własne

Przy założeniu kryterium styczności jednostek badawczych stwierdzono, że w latach 2002-2005 pogłębiła się ujemna zależność korelacyjna pod względem zmiennych $\mathrm{x}_{3}, \mathrm{x}_{7} \mathrm{i} \mathrm{x}_{8}$. Oznacza to, że następowała polaryzacja jednostek pod względem przeciętnego miesięcznego wynagrodzenia w przemyśle i budownictwie w zł, nakładów inwestycyjnych w przemyśle w zł/1 pracującego w przemyśle oraz sumarycznego wskaźnika uprzemysłowienia. Ujemną zależność korelacyjną wykazywał też badany obszar pod względem wartości brutto środków trwałych w przedsiębiorstwach przemysłowych w mln zł/1 pracującego w przemyśle. W badanym okresie wartość statystyki Morana dla wspomnianych zmiennych wykazywała spadek. Spadek odnotowano także w przypadku zmiennej $\mathrm{x}_{2}$, jednakże w obydwu przekrojach czasowych wykazywała ta zmienna występowanie dodatniej zależności jednostek na badanym obszarze. Zmiana kierunku zależności miała natomiast miejsce przy zmiennych $\mathrm{x}_{1}$, $\mathrm{x}_{5}, \mathrm{x}_{6}$, przy czym w przypadku produkcji sprzedanej przemysłu w zł/1 pracującego w przemyśle i produkcji sprzedanej przemysłu w mln zł/wartość brutto środków trwałych nastąpiło osłabienie wpływu jednostek sąsiednich na efekty działalności przemysłowej. W 2005 roku ujemny znak wartości statystyki Morana wskazywał na występowanie w sąsiedztwie geograficznym jednostek o różnych wartościach przyjętych zmiennych. Z kolei w przypadku zmiennej $\mathrm{x}_{6} \mathrm{w}$ badanym okresie miała miejsce sytuacja odwrotna. W 2005 r. województwo 
kujawsko-pomorskie wykazywało występowanie efektu sąsiedztwa, czyli osiaganie podobnych wartości wskaźnika przedsiębiorczości w jednostkach położonych blisko siebie pod względem geograficznym.

Badanie autokorelacji przestrzennej na podstawie odległości ekonomicznej pozwala stwierdzić, iż na badanym obszarze jednostki o zbliżonym potencjale ekonomicznym nie wykazywały do siebie podobieństwa. Przyjęte miary diagnostyczne rozwoju przemysłu wskazywały ujemną zależność autokorelacyjną. Zauważa się, że w badanym okresie statystyki Morana dla wszystkich cech wykazywały spadek wartości, przy czym najmniejsze zmiany były w przypadku produkcji sprzedanej przemysłu w zł/1 pracującego w przemyśle. Największy spadek zależności zaobserwowano natomiast w przypadku wskaźnika przedsiębiorczości. Oznacza to, iż efekty materialne działalności przemysłowej w dużym stopniu warunkowane są dotychczasowym zaangażowaniem rozwoju przemysłu, natomiast przedsiębiorczość nie zależy od potencjału społeczno-ekonomicznego, a bardziej od miękkich czynników lokalizacji i klimatu inwestycyjnego.

Graficzną prezentacją globalnej statystyki Morana jest wykres punktowy statystyki Morana. Pozwala on na wizualizację lokalnych związków przestrzennych (klastrów), obserwacji nietypowych (outliers), a także przestrzennej niestabilności (Anselin 1995). Zależność między regionem i sąsiadami określa się poprzez rozkład jednostek przestrzennych na układzie współrzędnych wyznaczonych przez oś x, na której odkłada się standaryzowaną wartość badanej zmiennej wyrażoną w liczbie odchyleń standardowych od średniej z próby. Na osi Y natomiast odznacza się standaryzowaną wartość zależności pomiędzy wartością zmiennej x w lokalizacji $i$ oraz wartościami tej zmiennej w lokalizacjach sąsiedzkich. Wykres dzieli się na ćwiartki względem punktu $(0,0)$. Punkty położone w dolnej lewej (LL) oraz prawej górnej (HH) ćwiartce świadczą o dodatniej autokorelacji przestrzennej, zaś punkty w lewej górnej (HL) i prawej dolnej (LH) ćwiartce oznaczają ujemną autokorelację przestrzenną (tab. 4) (Kopczewska 2007).

Tabela 4. Zależności między jednostką i sąsiadami

\begin{tabular}{|l|c|c|}
\hline & $\begin{array}{c}\text { Wartości niskie w jednostkach } \\
\text { sąsiedzkich }(\mathrm{L})\end{array}$ & $\begin{array}{c}\text { Wartości wysokie w jednostkach } \\
\text { sąsiedzkich }(\mathrm{H})\end{array}$ \\
\hline $\begin{array}{l}\text { Wartości wysokie } \\
\text { w jednostce } i(\mathrm{H})\end{array}$ & Ujemna autokorelacja przestrzenna & Dodatnia autokorelacja przestrzenna \\
\hline $\begin{array}{l}\text { Wartości niskie } \\
\text { w jednostce } i(\mathrm{~L})\end{array}$ & Dodatnia autokorelacja przestrzenna & Ujemna autokorelacja przestrzenna \\
\hline
\end{tabular}

Źródło: Opracowanie własne na podstawie Kopczewska 2007

Wykres punktowy Morana może być narzędziem diagnostyki obserwacji nietypowych w stosunku do globalnej tendencji (obserwacje w kwadratach HL i LH). Może także wskazywać tendencje polaryzacji badanych regionów i przestrzenną heterogeniczność. 

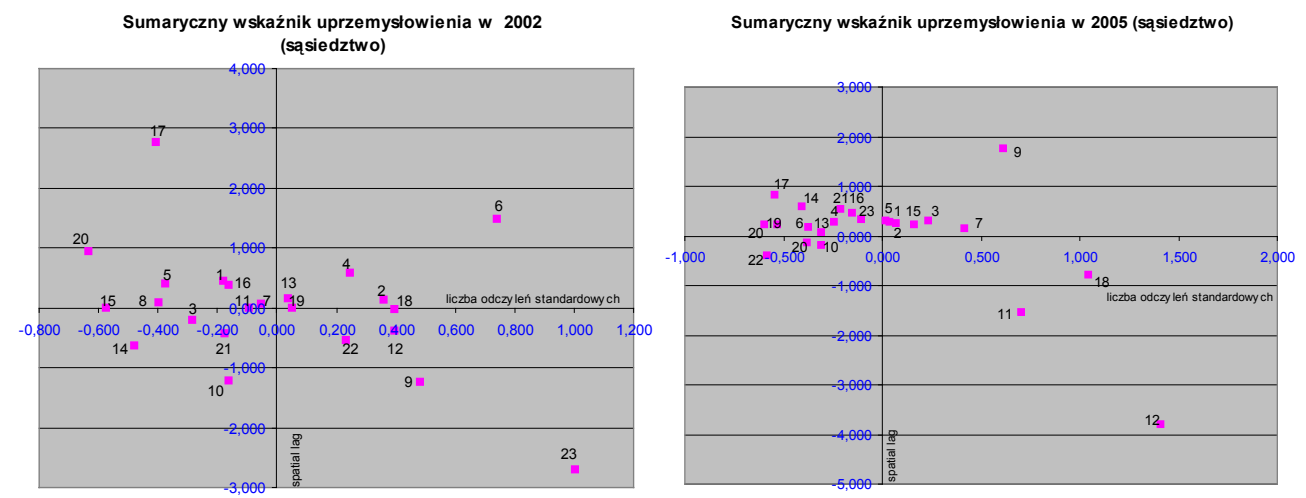

Ryc. 1. Rozkład lokalnej statystyki Morana w woj. kujawsko-pomorskim dla wskaźnika sumarycznego rozwoju przemysłu w 2002 i 2005 r. przy założeniu wag styczności Oznaczenia powiatów:

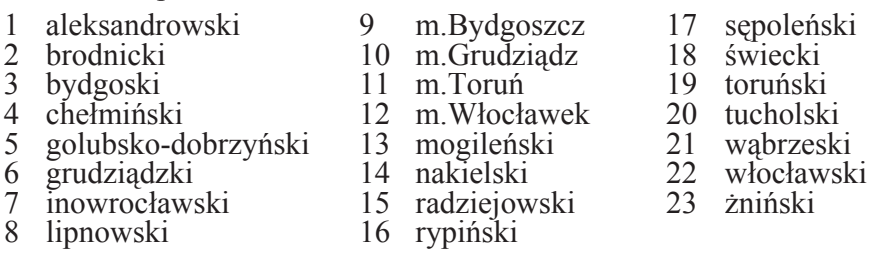

Przeprowadzone badania zależności przestrzennej powiatów woj. kujawsko-pomorskiego przy założeniu wag styczności wskazują, iż w przyjętym okresie badawczym zaobserwować można tendencję do polaryzacji przestrzennej pod względem rozwoju przemysłu. Przyjęte jednostki badawcze koncentrują się w kwadratach HL i LH (ryc. 1), co oznacza ujemną autokorelację przestrzenną. Skupianie się w bliskim sąsiedztwie jednostek o podobnych wartościach jest słabo widoczne, przy czym w większym stopniu dostrzegalne jest skupianie się jednostek o niskich wartościach (słabo zindustrializowany obszar Borów Tucholskich). $\mathrm{Z}$ analizy wykresów Morana dla przyjętych cech diagnostycznych wynika też wysoka pozycja miasta Bydgoszcz. Miasto to wykazując wysokie wskaźniki rozwoju przemysłu miało dodatnią autokorelację z jednostkami sąsiedzkimi. Zauważa się też odmienną pozycję pozostałych większych miast badanego obszaru. Powiaty m. Włocławek i m. Toruń wykazując wysokie wartości wskaźników uprzemysłowienia otoczone są powiatami o niskich wskaźnikach. 



Ryc. 2. Rozkład lokalnej statystyki Morana w woj. kujawsko-pomorskim dla wskaźnika sumarycznego rozwoju przemysłu w 2002 i 2005 r. przy założeniu odległości ekonomicznej

Biorąc pod uwagę odległość ekonomiczną (ryc. 2) zauważa się tendencję do klastowania jednostek badawczych regionów w ćwiartce LL. Oznacza to skupianie się jednostek o niskich wskaźnikach rozwoju przemysłu w sąsiedztwie jednostek o podobnych parametrach. Wykresy punktowe Morana wyznaczone dla jednostek woj. kujawsko-pomorskiego na podstawie odległości ekonomicznej w dużej mierze pokrywają się w tym względzie w wynikami badań opartych na odległości styczności. Skupienie jednostek w ćwiartce LL tworzą powiaty tucholski i sępoleński (Bory Tucholskie), do których podobieństwo wykazuje powiat lipnowski. W zakresie przyjętych cech badawczych w ćwiartce LL lokalizował się też często powiat nakielski, położony w zachodniej części województwa, sąsiadujący z powiatem sępoleńskim, a także powiat włocławski graniczący z powiatem lipnowskim, położony w południowo-wschodniej części województwa. Z kolei autokorelacja dodatnia zobrazowana na wykresie punktowym Morana w ćwiartce HH w latach 2002-2005 ewaluowała w zakresie przyjętych miar. Skupianie jednostek o wysokich wskaźnikach rozwoju przemysłu w sąsiedztwie jednostek o wysokich parametrach miało różny wymiar przestrzenny. Ogólnie można stwierdzić, że jednostką dodatnio skorelowaną z sąsiednimi w zakresie wysokich parametrów rozwoju przemysłu było m. Bydgoszcz. Do tej jednostki w wybranych parametrach podobną tendencję autokorelacyjną wykazywało m. Toruń i powiat brodnicki (z miastem Brodnica). Natomiast na jednostkę odstającą o wysokich wskaźnikach położoną w sąsiedztwie jednostek o niskich parametrach kreuje się m. Włocławek. Z kolei odwrotnie ukształtowaną ujemną autokorelację wykazują powiaty rypiński, aleksandrowski oraz m. Grudziądz. W sąsiedztwie wspomnianych jednostek o niskich wskaźnikach rozwoju przemysłu występują jednostki o wysokich wskaźnikach.

Przeprowadzona eksperymentalnie analiza zależności autokorelacyjnych pod względem rozwoju działalności przemysłowej i oddziaływań przestrzennych tej działalności wydaje się być bardzo pomocną metodą w identyfikowaniu przemysłowych struktur przestrzennych. Pozwala określić wzorce przestrzennej heterogeniczności oraz inne wzorce zależności przestrzennej. Za pomocą wspomnianej metody orzec można niski stopień zależności przestrzennych jednostek w zakresie rozwoju przemysłu oraz dostrzec tendencję do polaryzacji rozkładu działalności przemysłowej z wyraźnie dominującą pozycją m. Bydgoszcz pozy- 
tywnie oddziaływującego na jednostki sąsiedzkie oraz tendencję do alienacji miast Toruń i Włocławek. Miasta te osiagają wysoki poziom rozwoju działalności przemysłowej, przy czym ich potencjał nie jest wystarczający do pobudzenia działalności przemysłowej w jednostkach sąsiedzkich. Co ciekawe, tendencja ta widoczna jest niezależnie od przyjętych miar odległości między jednostkami. Problemem rzetelnej analizy pozostaje dobór właściwych miar diagnostycznych, których dostępność jest bardzo ograniczona zasadami zachowania tajemnicy statystycznej przez GUS oraz poziom agregacji jednostek przestrzennych. W skali regionalnej analizy na płaszczyźnie powiatów uśredniają poziom rozwoju przemysłu, zwłaszcza w mniejszych miastach i otaczających je terenach wiejskich, jednakże jedynie na tej płaszczyźnie agregacji przestrzennej można uzyskać szerszy wachlarz statystycznych materiałów źródłowych.

Podsumowując należy stwierdzić, że badanie struktur (układów) przemysłowych i ich ewolucji w dobie globalizacji wymaga dogłębnego poznania zjawisk i procesów uruchomionych w nurcie przemian globalnych oraz doprecyzowania podstaw merytorycznych przedmiotu badań geografii przemysłu. Przemysł w dobie globalizacji należy rozumieć nie tylko jako dział gospodarki narodowej obejmujący wydobywanie bądź pozyskiwanie surowców mineralnych, roślinnych i zwierzęcych oraz ich przetwarzanie za pomocą obróbki fizycznej lub chemicznej na wyroby gotowe służące potrzebom człowieka (Kortus 1986), ale jako dziedzinę produkcyjnych działań człowieka, których rezultat weryfikowany jest przez rynek, np. jako zespół konkurencyjnych rywalizujących ze sobą firm, którego celem jest sprzedaż swoich produktów, względnie usług nabywcom (Kieżun 1997). Tak zdefiniowany wymiar funkcjonowania działalności przemysłowej nie w pełni oddaje istotę działalności przemysłowej we współczesnym świecie, ale pozwala uchwycić zjawiska typowe dla współczesnej gospodarki. Gospodarka globalna to z jednej strony umiędzynarodowienie, z drugiej polaryzacja gospodarcza (przepaść technologiczna). Współczesna geografia przemysłu powinna dążyć do wyjaśnienia, dlaczego coraz powszechniejsze relacje w skali globalnej prowadzą do utrwalania się nierówności w skali lokalnej.

\section{Literatura}

Anselin L. 1995, Lokal Indicators of Spatial Association - LISA, Geographical Analysis

Anselin L., Bera A. 1998, Spatial Dependence in Linear Regression Models with an Introduction to Spatial Econometrics, [in:] Handbook of Applied Economic Statistics, eds. A. Ullah, D. Giles, New York

Bivand R. 1980, Autokorelacja przestrzenna a metody analizy statystycznej w geografii, [w:] Analiza regresji w geografii, red. Z. Chojnicki, PWN, Poznań

Bivand R. 1981, Modelowanie geograficznych układów czasoprzestrzennych, PWN, WarszawaPoznań

Chardonnet J. 1955, Podstawowe typy kompleksów przemystowych, Przegląd Zagranicznej Literatury Geograficznej, z. 5, Warszawa

Cliff A., Ord J.K. 1973, Spatial Autocorrelation, London

Czyż T. 1978, Metody generalizacji układów przestrzennych, PWN, Poznań

Delimitacja okręgów przemysłowych-zmiany terytorialne zaistniałe w latach 1978-1988, 1994, Studia i Analizy Statystyczne, GUS, Warszawa

Delimitacja okręgów przemystowych, 1982, GUS, Warszawa

Domański R. 1982, Teoretyczne podstawy geografii ekonomicznej, PWE, Warszawa

Fierla I. 1984, Geografia przemystu Polski, PWE, Warszawa 
Fierla I. 1987, Lokalizacja przemystu, PWE, Warszawa

Flejterski S. 2001, E-finanse a makro-, mezzo i mikroekonomia. Wstęp do analizy kosztów i korzyści, [w:] ,Nowa gospodarka” i jej implikacje dla dlugookresowego wzrostu w krajach posocjalistycznych, red. G. Kołodko, Wydawnictwo Wyższej Szkoły Przedsiębiorczości i Zarządzania im. Leona Koźmińskiego, Warszawa

Gierańczyk W., Stańczyk A. 2000, Ksztaltowanie sie przestrzeni przemysłowych w Polsce, [w:] Środowisko przyrodnicze i gospodarka Dolnego Ślaska u progu trzeciego tysiaclecia, Materiały XLIX Zjazdu PTG, Instytut Geograficzny Uniwersytetu Wrocławskiego, Wrocław, s. 181-185

Gierańczyk W., Stańczyk A. 2001, Okręi przemystowe w Polsce u progu XXI w., [w:] Problemy przemian struktur przemysłowych $w$ procesie wdrażania regut gospodarki rynkowej, pod red. Z. Zioło, Prace Komisji Geografii Przemysłu PTG nr 2, Warszawa-Kraków

Haggett P., Cliff A.D., Frey A. 1977, Locational analysis in human geography, London

Hirzel M. i in. 1997, Alternativen beim Outsourcing von Yerwaltungsdienst, ,JO Management”, nr 3

Kawalec W. 1965, Okręi przemystowe i regiony ekonomiczne w Polsce, PWE, Warszawa

Kawalec W. 1970, Wybrane problemy struktury przestrzennej przemystu, Biuletyn KPZK, z. 56, Warszawa

Kieżun W. 1997, Sprawne zarzqdzanie organizacja, SGH, Warszawa

Kopczewska K. 2007, Ekonometria i statystyka przestrzenna, CeDeWU.pl Wydawnictwa Fachowe, Warszawa

Kortus B. 1986, Wstęp do geografii przemystu, PWN, Warszawa

LaSage J. 1999, Spatial Econometrics, [in:] The Web Book of Regional Science, Regional Research Institute, Morgantown

Leszczycki S., Lijewski T. 1974, Geografia przemystu Polski, PWN, Warszawa

Misztal S. 1970, Przemiany $w$ strukturze przestrzennej przemystu na ziemiach polskich $w$ latach 1860-1965, Studia KPZK PAN, t. XXXI, Warszawa

Pakuła L. 1978, Problemy teoretyczno-badawcze form koncentracji przestrzennej przemystu, Folia Geographica, series Geogr-Oeconom., vol. VI

Polityka wspierania klastrów: najlepsze praktyki: rekomendacje dla Polski, 2004, Rekomendacje nr 11, Instytut Badań nad Gospodarką Rynkową, Gdańsk

Porter M.E. 2001, Porter o konkurencji, PWE, Warszawa

Problematyka ośrodka przemystowego w akademickim ksztatceniu nauczycieli geografii, 1990, pod red. Z. Zioło, Materiały i Sprawozdania WSP w Krakowie, Wydawnictwo Naukowe WSP, Kraków

Ratajczak W. 1980, Analiza i modele wpływu czynników społeczno-gospodarczych na ksztaltowanie się sieci transportowej, PWN, Poznań

Secomski K. 1956, Wstęp do rozmieszczenia sit wytwórczych, Warszawa

Skrzypczyński P. 2006, Analiza synchronizacji cykli koniunkturalnych w strefie euro, Materiały i Studia, nr 210, Warszawa

Smirnov O., Anselin L. 2001, Fast Maximum Likelihood Estimation of Very Spatial Autoregressive Models: a Characteristic Polynominal Approach, Computational Statistic \& Data Analysis

Stryjakiewicz T., Wajda E., 2003, Organizacja przestrzenna grup kapitałowych jako problem badawczy geografii ekonomicznej, [w:] Przemyst w procesie globalizacji, red. Z. Zioło, Prace Komisji Geografii Przemysłu PTG nr 6, Warszawa-Kraków

Wrzosek A. 1972, Główne okręgi przemystowe Polski, PZWS, Warszawa

Zioło Z. 1971, Stan badań nad problemem struktury przestrzennej przemystu i jej form koncentracji, Materiały Informacyjne WKPG w Krakowie, z. 40, Prace Geograficzne V, Kraków

Zioło Z. 2003, Ksztaltowanie się przedsiębiorstw przemysłowych w procesie globalizacji, [w:] Przemyst w procesie globalizacji, red. Z. Zioło, Prace Komisji Geografii Przemysłu PTG nr 6, WarszawaKraków 


\section{Research into Polish industrial structures in the globalization era: the industrial spatial structure}

Globalization as the drive of socio-economic and political transformations shapes the new order of the modern world. The imperative of constant economic growth forces the search for new sources of optimization of industrial activity, e.g. through extensive division of labour, searching for cheap labour, specialization of activity, tightening the bonds between particular sectors of the national economy, using new technological achievements and new organizational solutions (production fragmentation), and political activity (systematic reduction of barriers in goods, services and capital global flow). Globalization also causes far-reaching changes in the functioning of industry. As a consequence, the object of research in industrial geography changes, as well as the theme- and research range of industrial structures (systems). Traditionally the analysis of structural systems was conducted on the planes of: divisions (branches), ownership, size, and space. In the globalization era, as a result of strong influence of science and technology on industry, especially in organizational, technological, but also logistic spheres, individuation of each of the above-mentioned structures becomes highly problematic.

In the light of the above, the author of the present paper examines the applicability of the spatial auto-corellation analysis in identification of patterns of spatial dependencies and spatial heterogeneity of industrial activity, on the example of the Kujawsko-pomorskie voivodship. The main assumption of auto-corellation analysis is based on the claim that the intensity of phenomena in a spatial unit depends on their level in neighbouring units. Experimental analysis of auto-corellative dependencies with respect to the industrial activity development and spatial influence of this activity seems to be a helpful method in identifying industrial spatial structures. It enables determination of patterns of spatial heterogeneity and other patterns of spatial dependencies. Using this method enables to diagnose a low degree of spatial dependency of units with respect to industrial development, and to notice the tendency of polarization of the industrial activity distribution. 